\title{
Economics of maize production in Haveri district
}

\author{
SHILPA P. CHOWTI AND H. BASAVARAJA
}

Received : 21.07.2015; Revised : 24.08.2015; Accepted : 14.09.2015

\begin{abstract}
The present study was conducted in Haveri district of Karnataka state. The required primary data was collected from sample farmers through personal interview method with the help of pre-tested and well structured schedule. The study attempted to examine the cost and returns structure in major maize hybrids. A sample of 120 farmers from Haveri district was selected through multistage stage random sampling technique. Per hectare cost of cultivation was slightly more in NK-6240 (Rs. 37,494) compared to CP-818 (Rs. 34,369) and Sunny (Rs. 36,120) with a respective benefit cost ratio of 1.88, 1.79 and 1.83. In the study area cultivation of CP-818 was found to be profitable than other two hybrids. In Kharif season, per hectare cost of maize (Rs. 35,716) was high (Rs. 35,716) compared to Rabi (Rs. 30,157) but the benefit cost ratio was more in Rabi $(2.28)$ than in Kharif (1.80).
\end{abstract}

KEY WORDS : Maize hybrids, Cost of cultivation, Season wise

How to cite this paper : Chowti, Shilpa P. and Basavaraja, H. (2015). Economics of maize production in Haveri district. Internat. J. Com. \& Bus. Manage, 8(2): 218-223.

SHILPA P. CHOWTI, Department of Agricultural Economics,

University of Agricultural Sciences, DHARWAD (KARNATAKA) INDIA

Email: agrichoutishilpa@gmail.com

Authors' affiliations:

H. BASAVARAJA, Department of Agricultural Economics, University of Agricultural Sciences, DHARWAD (KARNATAKA) INDIA 